\title{
A Study on Lap Joint Welding of Thin Plate ASTM F1684 Using Fiber Laser Welding
}

\author{
Jaewoong Kim ${ }^{1}$, Younghyun Kim ${ }^{1}$, Jisun Kim ${ }^{1}$, Yongtai Kim ${ }^{2}$, Dongwoo Kim ${ }^{2}$, Sungwook Kang ${ }^{3}$ (D) \\ and Changmin Pyo ${ }^{1, * \mathbb{D}}$ \\ 1 Smart Mobility Materials and Components R\&D Group, Korea Institute of Industrial Technology, \\ Gwangju 61012, Korea; kjw0607@kitech.re.kr (J.K.); kyh1927@kitech.re.kr (Y.K.); kimjisun@kitech.re.kr (J.K.) \\ 2 Cargo Containment System Research Dep't, Hyundai Heavy Industries, Seoul 03058, Korea; \\ yongtd@hhi.co.kr (Y.K.); dwkim@hhi.co.kr (D.K.) \\ 3 Transport Machine Components R\&D Group, Korea Institute of Industrial Technology, Jinju-si 52845, Korea; \\ swkang@kitech.re.kr \\ * Correspondence: changmin@kitech.re.kr; Tel.: +82-62-600-6080
}

Citation: Kim, J.; Kim, Y.; Kim, J.; Kim, Y.; Kim, D.; Kang, S.; Pyo, C. A Study on Lap Joint Welding of Thin Plate ASTM F1684 Using Fiber Laser Welding. Processes 2021, 9, 428. https://doi.org/10.3390/pr9030428

Academic Editor: Ireneusz Zbicinski

Received: 9 February 2021

Accepted: 22 February 2021

Published: 27 February 2021

Publisher's Note: MDPI stays neutral with regard to jurisdictional claims in published maps and institutional affiliations.

Copyright: (c) 2021 by the authors. Licensee MDPI, Basel, Switzerland. This article is an open access article distributed under the terms and conditions of the Creative Commons Attribution (CC BY) license (https:/ / creativecommons.org/licenses/by/ $4.0 /)$.

\begin{abstract}
The International Maritime Organization (IMO) has developed stricter regulations on emission standards for sulfur oxides, etc., and the demand for Liquefied Natural Gas (LNG) is increasing as an alternative to satisfy these standards. This study relates to fiber laser welding, an approach which offers high-speed welding and low welding deformation for ASTM F1684, which has a low coefficient of thermal expansion (CTE) even in a cryogenic environment. In this study, through three preliminary experiments using $0.25 \mathrm{~mm}$ thick Invar, the conditions required to secure sufficient penetration depth and back bead were identified. Through the cross-sectional observation analysis, the welding conditions without defects were identified and the trend of penetration shape according to increasing welding speed was identified. Following a lap joint laser welding experiment under the secured conditions, the mechanical properties were evaluated through the shear strength test and the heat influence range of a fiber laser was identified through the temperature measurement of a welding part. As a result, it was confirmed that the shear strength of the lap joint laser welding part was $86.8 \%$ that of the base metal.
\end{abstract}

Keywords: fiber laser welding; lap joint welding; tensile strength; ASTM F1684

\section{Introduction}

To reduce marine environmental pollution, the International Maritime Organization (IMO) has strictly regulated the sulfur content standard for ship fuel oil, reducing it from $3.5 \% \mathrm{~m} / \mathrm{m}$ (Mass by mass) to $0.5 \%$ in January 2020 [1]. As typical offshore petroleumbased fuels cannot meet this regulation, the demand for liquefied natural gas (LNG) as an alternative fuel is increasing and the demand for ships that use LNG as fuel is rising as well [2,3]. When LNG is used, the emission of sulfur oxides (SOx) is reduced by $60-90 \%$ and the emission of nitrogen oxides (NOx) is about 30\% lower. In terms of $\mathrm{CO}_{2}$ emission, reductions of more than $20 \%$ can be achieved [2-5].

Natural Gas (NG) has a boiling point of $-163{ }^{\circ} \mathrm{C}$, and cryogenic conditions are required for its storage and transportation in a liquefied state. Since general metals cannot be used due to their brittleness under the above condition, care should be taken when selecting materials [6]. Additionally, many researches of cryogenic metals for treating LNG were performed [7-10].

ASTM F1684 is known to have a low coefficient of thermal expansion (CTE) from room temperature to around Curie temperature $\left(230{ }^{\circ} \mathrm{C}\right)$, and excellent mechanical properties in cryogenic environments. Due to these characteristics, it is widely used as a highreliability and high-precision material, in space equipment, precision equipment, and LNG tanks [11-13]. 
There are quite a few welding studies on ASTM F1684. Harrison et al. confirmed that the low thermal expansion characteristic, which is the main characteristic of Invar, is maintained when using SLM (selective laser melting), a specific 3D printing technology that completely melts and fuse metal powder using a high-density laser [14]. Yakout et al. applied SLM and confirmed that laser energy density of SLM affect the density and microstructure of Invar [15]. Zhan et al. compared the residual stress and deformation amount for various parameters by applying the multi-layer Laser-MIG (Metal Inert Gas) Hybrid Welding method to $19.5 \mathrm{~mm}$ thick Invar. As a result, residual stress and deformation were reduced in three-layer welding compared to two-layer welding [16]. Zhan et al. compared MIG Welding with Layer Laser-MIG Hybrid Welding of Invar in terms of welding efficiency and deformation and found that the laser-MIG hybrid welding showed less deformation than MIG welding and the welding time was also reduced by eight times [17]. Bharat et al. applied friction stir welding to Invar with a thickness of $12.7 \mathrm{~mm}$ and per-formed a cross sectional analysis and compared mechanical properties depending on pin tools. As a result, the coefficients of thermal expansion, tensile strength, and micro hardness of the welds were essentially unchanged from the parent material, and the pin tool produced remnant-free welds with insignificant tool wear [18]. Yue et al. applied friction stir welding to $3.0 \mathrm{~mm}$ thick Invar and achieved defect-free welding conditions through X-ray analysis, cross-sectional analysis, and mechanical property tests depending on the parameters [19]. Corbacho et al. applied GTAW (gas tungsten arc welding) to Invar with a thickness of $4 \mathrm{~mm}$ to $8 \mathrm{~mm}$ and analyzed its microstructure. As a result, GTAW, a low heat input welding process, exhibited a narrow HAZ(Heat Affected Zone) area, and Invar requires attention because surface and grain-boundary oxidation are prone to occur [20]. Wang et al. performed lap joint welding by applying the GTAW welding method to Invar of $0.7 \mathrm{~mm}$ and $1.0 \mathrm{~mm}$ thickness and compared its microstructure, hardness, and shear tensile characteristics depending on duty cycle size. As a result, the tensile shear force is directly proportional to the duty cycle, and the maximum tensile shear force is $4425 \mathrm{~N}$ [11]. Kim et al. applied fiber laser welding using cold wire to a cross-shaped Invar of $1.5 \mathrm{~mm}$ and $3.0 \mathrm{~mm}$ thickness. By optimizing the welding conditions for the cross-shaped structure, which previously required 4 welding passes, the number of passes was reduced to 2 [21].

Base on the above studies, this study was conducted to confirm the welding feasibility of ultra-thin plates with a thickness of $1 \mathrm{~mm}$ or less. To this end, the study was conducted with fiber laser welding with easy systemization, automation, and robotization, enabling automatic welding, high-speed welding, and low welding deformation.

For this study, a preliminary experiment was performed with the laser power and welding speed as variables to secure an appropriate amount of heat input and a stable back bead when welding the $0.2 \mathrm{~mm}$ thick ASTM F1684 lap joint through fiber laser welding. After performing lap joint welding under the welding conditions obtained through the preliminary experiment, the bead width, bead height, weld zone width, and penetration were analyzed through cross-sectional observation, and the shear strength of the weld zone was compared through a shear test.

\section{Materials and Methods}

In this study, a lap joint fiber laser welding experiment was performed on ASTM F1684 with a thickness of $0.25 \mathrm{~mm}$ and the optimum welding conditions were derived through three series of preliminary experiments, cross-sectional analyses, and shear strength tests. The material used in this study is ASTM F1684 and its chemical composition is shown in Table 1. Further mechanical properties are shown in Table 2. 
Table 1. Chemical composition of ASTM F1684 [21].

\begin{tabular}{ccccc}
\hline Material & \multicolumn{5}{c}{ Composition $\mathbf{( w t} \%)$} \\
\hline \multirow{3}{*}{ ASTM F1684 } & $\mathbf{N i}$ & $\mathbf{M o}$ & $\mathbf{C}$ & $\mathbf{M n}$ \\
\cline { 2 - 5 } & 36 & $\sim 0.5$ & $\sim 0.1$ & $\sim 0.06$ \\
\cline { 2 - 5 } & $\mathbf{P}$ & $\mathbf{S}$ & $\mathbf{S i}$ & $\mathbf{C r}$ \\
\cline { 2 - 5 } & $\sim 0.025$ & $\sim 0.025$ & $\sim 0.35$ & $\sim 0.5$ \\
\hline
\end{tabular}

Table 2. Mechanical properties of ASTM F1684 [21].

\begin{tabular}{ccc}
\hline $\begin{array}{c}\text { Coefficient of Thermal Expansion } \\
(\mathbf{m m} / \mathbf{m m K})\end{array}$ & Young's Modulus (GPa) & Density (kg/m $\left.\mathbf{m}^{\mathbf{3}}\right)$ \\
\hline $1.2 \times 10^{-6}$ & 148.0 & 8100.0 \\
\hline
\end{tabular}

In this study, a specimen with a size of $100 \mathrm{~mm} \times 200 \mathrm{~mm} \times 0.25 \mathrm{~mm}$ was used for the lap joint fiber laser welding experiment. After overlapping two plates by about $30 \mathrm{~mm}$, a welding experiment was performed on the overlapped central part, and its schematic diagram is shown in Figure 1.

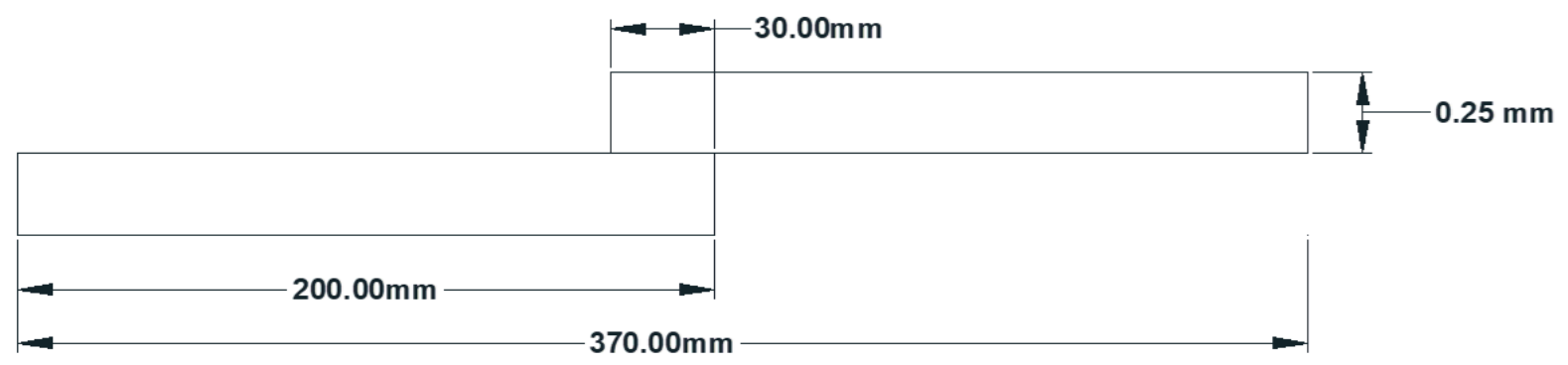

Figure 1. ASTM F1684 thin plate lap joint welding test piece schematic diagram.

When a thin plate is used, significant welding deformation can occur, so a jig is required to control the deformation. The layout of a welding system with the jig installed is shown in Figure 2.

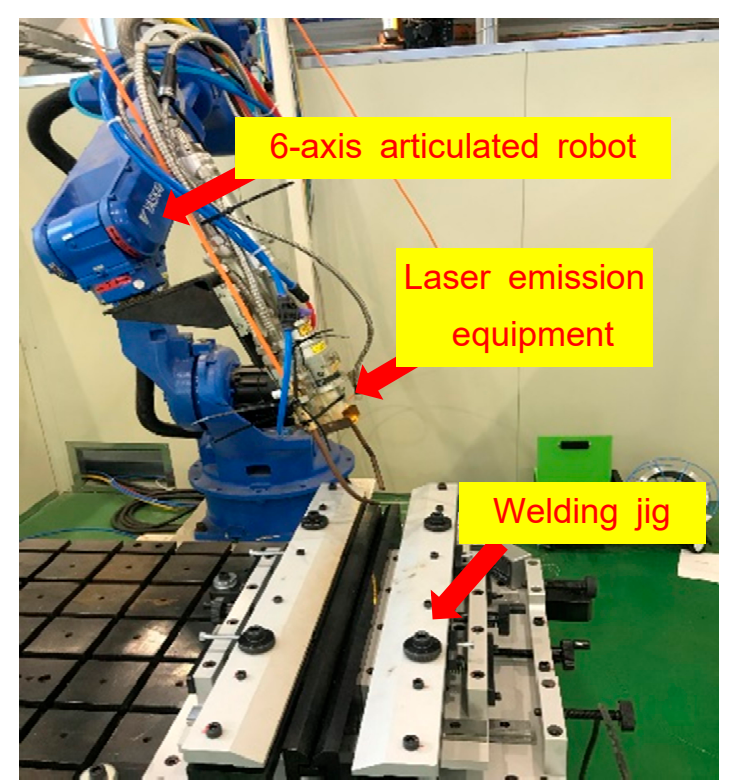

Figure 2. Fiber laser welding system with jig. 
In this study, all surfaces except $20 \mathrm{~mm}$ around the welding line were tightly fixed in order to control the welding deformation as much as possible and to minimize the gap between the specimens for the lap joint welding. Two specimens were inserted and fixed in the middle of the jig as shown in Figure 3.
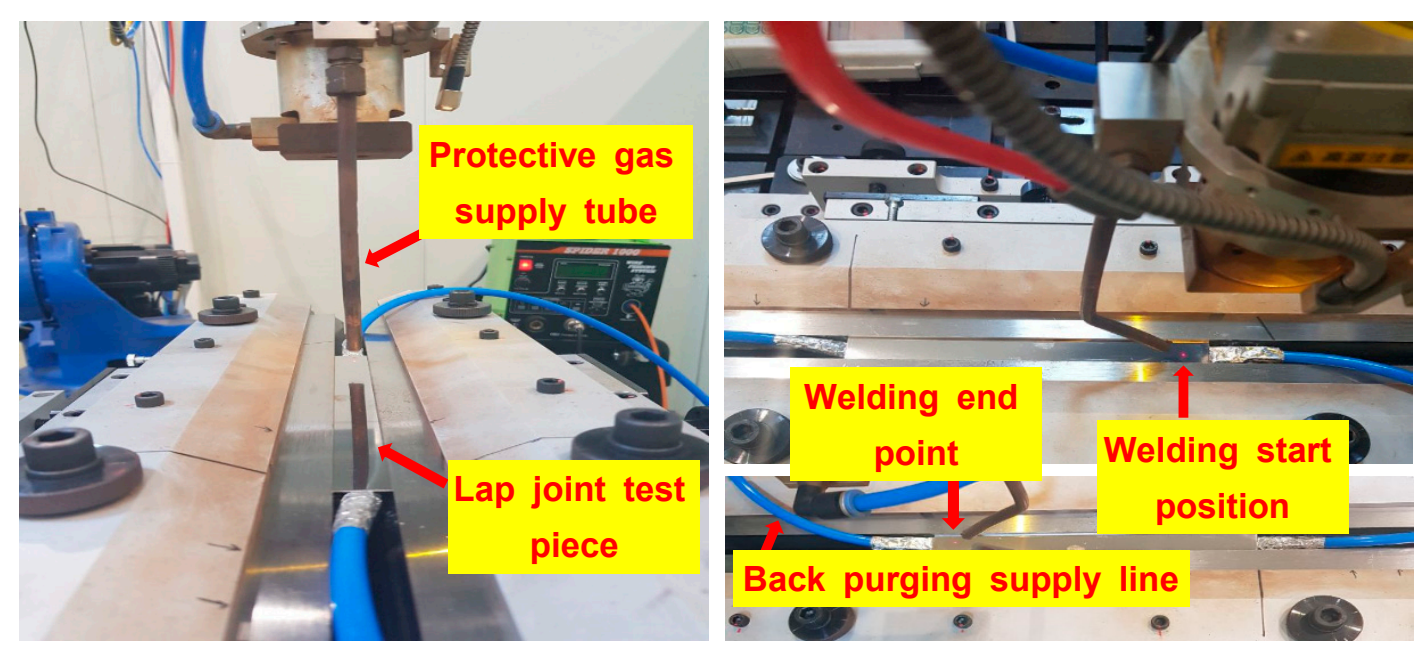

Figure 3. Lap joint welding jig setting.

For laser welding, Miyachi $5 \mathrm{~kW}$ fiber laser welding equipment was used. The equipment consists of a laser welding oscillator, an optical system, a controller, and a chiller, as shown in Figure 4 . The optical system used in this study has a spot diameter of $400 \mu \mathrm{m}$, a focal length of $148.8 \mathrm{~mm}$, and a focal depth of $6 \mathrm{~mm}$. The 6-axis automatic robot was from Yaskawa.

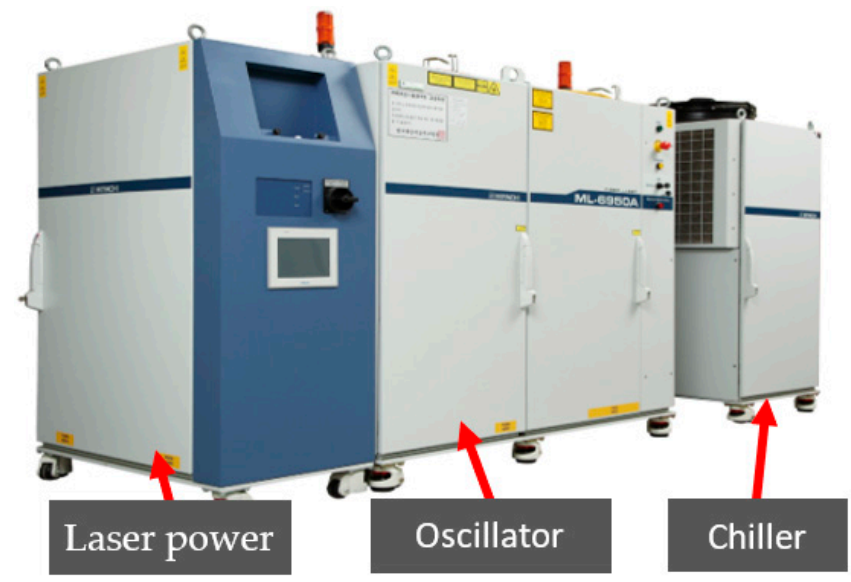

Figure 4. Fiber laser equipment.

A macro test was performed to analyze weld zone, width, and penetration. The test was performed based on ASTM E340 and the environmental conditions were a temperature of $23{ }^{\circ} \mathrm{C}$ and a humidity of $43 \% \mathrm{RH}$, and $3 \%$ Nital was used as etching solution. The etched cross-section was observed using equipment made by Olympus and is shown in Figure 5. 

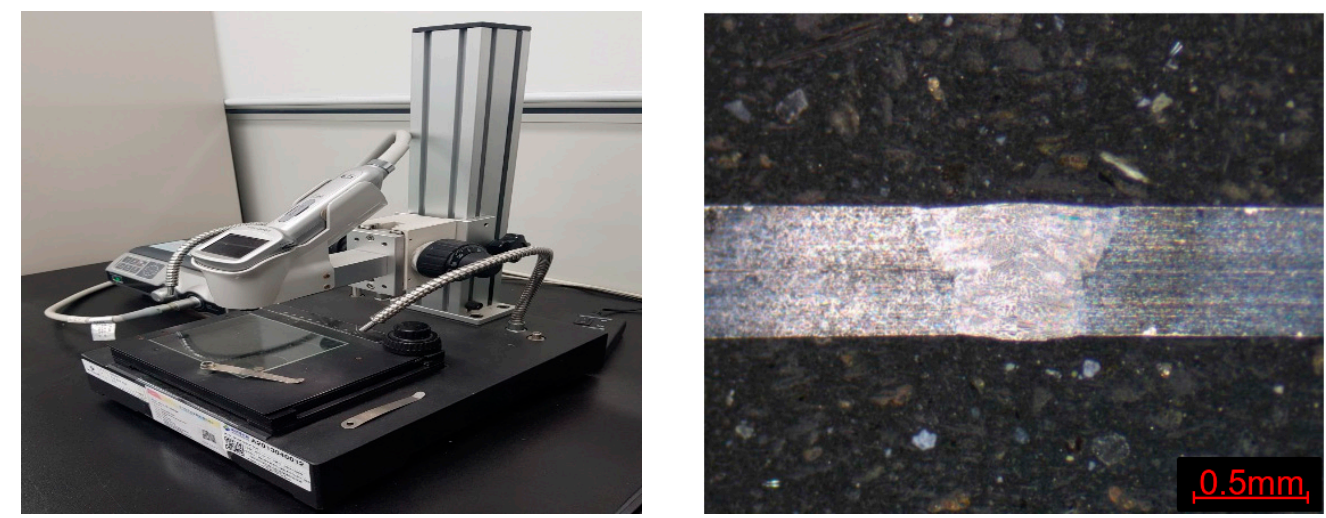

Figure 5. Optical microscope equipment and cross-section of a sample.

A shear tensile strength test was performed to analyze the fracture shape of a welding part and measure its strength. The tensile strength was measured using the Hounsfield H10KS universal testing machine (UTM), as shown in Figure 6. To measure the shear strength, a test piece with a size of $370 \mathrm{~mm} \times 20 \mathrm{~mm} \times 0.25 \mathrm{~mm}$ was made, as shown in Figure 7 . The tensile speed was fixed at $5 \mathrm{~mm} / \mathrm{min}$.

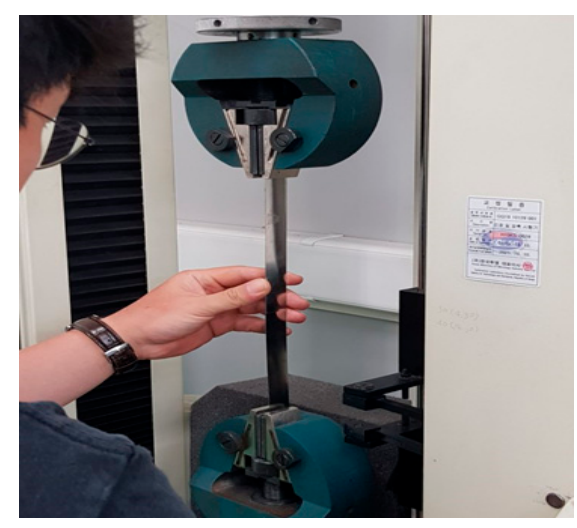

Figure 6. Tensile testing equipment.

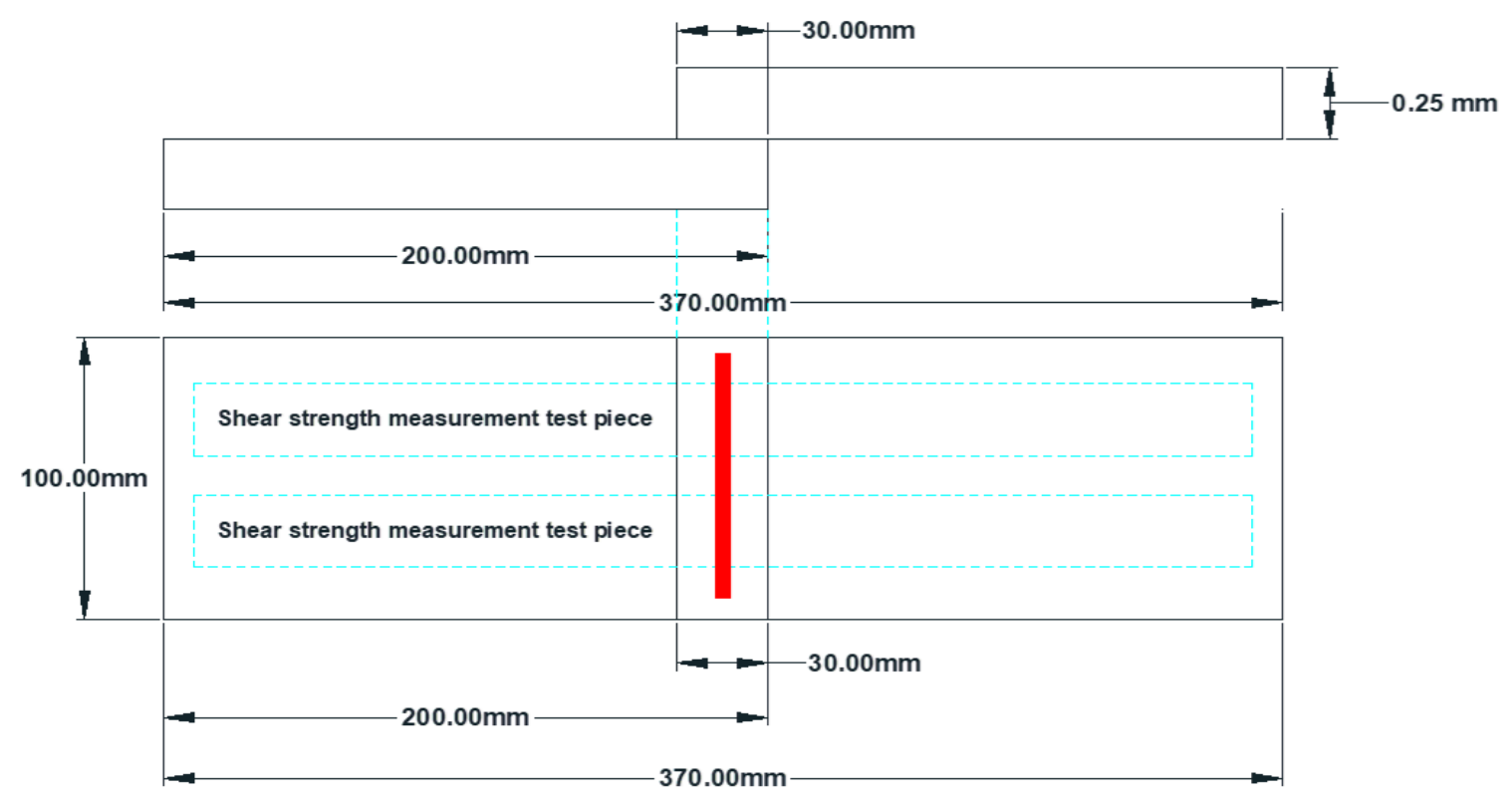

Figure 7. Schematic diagram of tensile test piece. 


\section{Results}

To select an appropriate amount of heat input, the welding speed was fixed at $1 \mathrm{~m} / \mathrm{min}$ and the first preliminary experiment of five cases was performed using the laser output value as a variable. Each experiment condition is shown in Table 3.

Table 3. 1st Conditions of laser welding for $0.25 \mathrm{~mm}$ thickness of ASTM F1684.

\begin{tabular}{cc}
\hline Welding Parameters & Experimental Conditions \\
\hline Laser power $(\mathrm{kW})$ & $0.50,0.55,0.60,0.65,0.70$ \\
Welding speed $(\mathrm{m} / \mathrm{min})$ & 1 \\
Defocus $(\mathrm{mm})$ & 0 \\
Shielding gas Ar $(\mathrm{L} / \mathrm{min})$ & 0 \\
Tilting angle \& Working angle $\left({ }^{\circ}\right)$ & 0 \\
\hline
\end{tabular}

After the welding experiment for each case, the welding part was visually observed and its appearance is as shown in Figure 8.

\begin{tabular}{|c|c|c|c|c|}
\hline 1) Welding direction & Weliling direction & Welding direction & 8 (8) Weldîng direction & (3) Welding direction \\
\hline $\begin{array}{l}\text { Unstable } \\
\text { laser power }\end{array}$ & $\begin{array}{l}\text { Unstable } \\
\text { laser }\end{array}$ & $\begin{array}{l}\text { Unstable } \\
\text { laser }\end{array}$ & $\begin{array}{l}\text { Burn through and } \\
\text { humping bead } \\
\text { formation }\end{array}$ & $\begin{array}{l}\text { Bum through and } \\
\text { humping bead } \\
\text { formation }\end{array}$ \\
\hline \multicolumn{5}{|c|}{ Welding speed (meter per minute, $\mathrm{m} / \mathrm{min}$ ) : $1 \mathrm{~m} / \mathrm{min}$} \\
\hline Case 1 & Case 2 & Case 3 & Case 4 & Case 5 \\
\hline Power: $0.50 \mathrm{~kW}$ & Power: $0.55 \mathrm{~kW}$ & Power: $0.60 \mathrm{~kW}$ & Power: $0.65 \mathrm{~kW}$ & Power: $0.70 \mathrm{~kW}$ \\
\hline
\end{tabular}

Figure 8. Surface geometry of the first experiment of Lap joint welding.

In Cases 1 and 2, there was no penetration due to welding failure. Case 3 showed partial welding and Cases 4 and 5 made a back bead through sufficient penetration, but there was also a humping bead. In addition, through laser power monitoring, it was confirmed that the high-power laser oscillated in the initial stage compared to the input power during low power welding, and it was further confirmed that its output was stable at $1 \mathrm{~kW}$ or more. The results are shown in Figure 9.
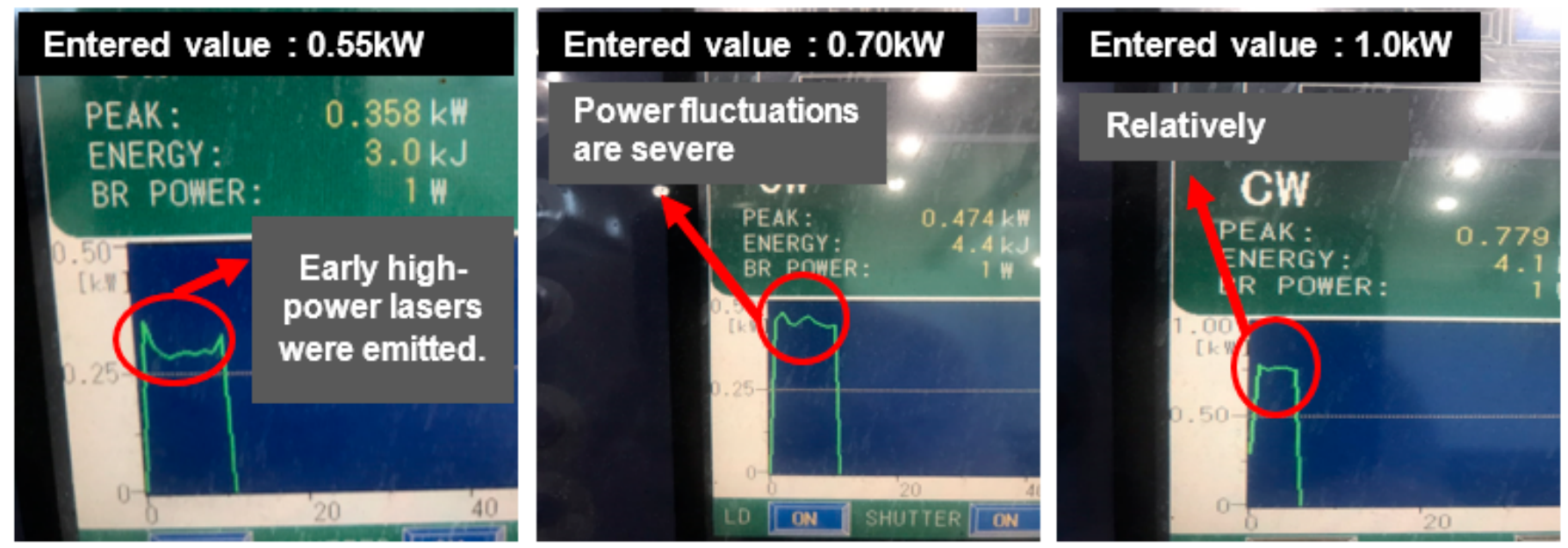

Figure 9. Laser power monitoring. 
It is necessary to increase the laser output power to avoid the welding defects seen in Cases 1 to 5 , and the second preliminary experiment for the five cases was performed using the welding speed as a variable after fixing the output value to $1 \mathrm{~kW}$ where stable laser power is generated. Each experimental condition is shown in Table 4.

Table 4. 2nd Conditions of laser welding for $0.25 \mathrm{~mm}$ thickness of ASTM F1684.

\begin{tabular}{cc}
\hline Welding Parameters & Experimental Conditions \\
\hline Laser power $(\mathrm{kW})$ & 1 \\
Welding speed $(\mathrm{m} / \mathrm{min})$ & $1.7,1.8,1.9,2.0,2.1$ \\
Defocus $(\mathrm{mm})$ & 0 \\
Shielding gas Ar $(\mathrm{L} / \mathrm{min})$ & 15 \\
Tilting angle \& Working angle $\left(^{\circ}\right)$ & 0 \\
\hline
\end{tabular}

After the welding experiment for each case, the welding part was visually observed and the results are as shown in Figure 10.

\begin{tabular}{|c|c|c|c|c|}
\hline $\begin{array}{l}\text { Welding direction } \\
\text { and through } \\
\text { humping bead }\end{array}$ & $\begin{array}{l}\text { Welding direction } \\
\text { Burn through } \\
\text { and } \\
\text { humping bead }\end{array}$ & $\begin{array}{l}\text { Welding direction } \\
\text { Burn through } \\
\text { and } \\
\text { humping bead }\end{array}$ & $\begin{array}{l}\text { Welding direction } \\
\text { Bivm througn } \\
\text { and } \\
\text { Lumping bead }\end{array}$ & $\begin{array}{l}\text { 2f Welding direction } \\
\text { Burn through } \\
\text { and } \\
\text { humping bead }\end{array}$ \\
\hline \multicolumn{5}{|c|}{ Laser Power: $1 \mathrm{~kW}$} \\
\hline $\begin{array}{c}\text { Case } 6 \\
\text { Speed: } 1.7 \mathrm{~m} / \mathrm{min}\end{array}$ & $\begin{array}{c}\text { Case } 7 \\
\text { Speed: } 1.8 \mathrm{~m} / \mathrm{min}\end{array}$ & $\begin{array}{c}\text { Case } 8 \\
\text { Speed: } 1.9 \mathrm{~m} / \mathrm{min}\end{array}$ & $\begin{array}{c}\text { Case } 9 \\
\text { Speed: } 2.0 \mathrm{~m} / \mathrm{min}\end{array}$ & $\begin{array}{c}\text { Case } 10 \\
\text { Speed: } 2.1 \mathrm{~m} / \mathrm{min}\end{array}$ \\
\hline
\end{tabular}

Figure 10. Surface geometry of the second lap joint welding experiment.

Cases 6 to 10 in the second preliminary experiment had sufficient penetration, leading to the creation of a back bead, but it was confirmed that burn through and humping beads were also produced at the same time. A burn through was created when molten metal flows to the opposite side of a test piece locally, and the humping bead is a welding defect that occurs due to excessive heat input when the molten metal supplied to the rear is supplied unstable. To control burn through and humping beads, it was judged that the amount of heat input needs to be reduced. Therefore, the welding speed was increased in the third preliminary test. The laser output power was fixed to $1 \mathrm{~kW}$, as in the second preliminary experiment, and then its speed was increased to $2.5 \mathrm{~m} / \mathrm{min}, 3.0 \mathrm{~m} / \mathrm{min}$, $3.5 \mathrm{~m} / \mathrm{min}, 4.0 \mathrm{~m} / \mathrm{min}$, and $4.5 \mathrm{~m} / \mathrm{min}$. An experiment was performed for five cases each and each experimental condition is shown in Table 5.

Table 5. 3rd Conditions of laser welding for $0.2 \mathrm{~mm}$ thickness of ASTM F1684.

\begin{tabular}{cc}
\hline Welding Parameters & Experimental Conditions \\
\hline Laser power $(\mathrm{kW})$ & 1 \\
Welding speed $(\mathrm{m} / \mathrm{min})$ & $2.5,3.0,3.5,4.0,4.5$ \\
Defocus $(\mathrm{mm})$ & 0 \\
Shielding gas Ar $(\mathrm{L} / \mathrm{min})$ & 15 \\
Tilting angle \& Working angle & 0 \\
\hline
\end{tabular}

After the welding experiment for each case, the welding part was visually observed as shown in Figure 11. 


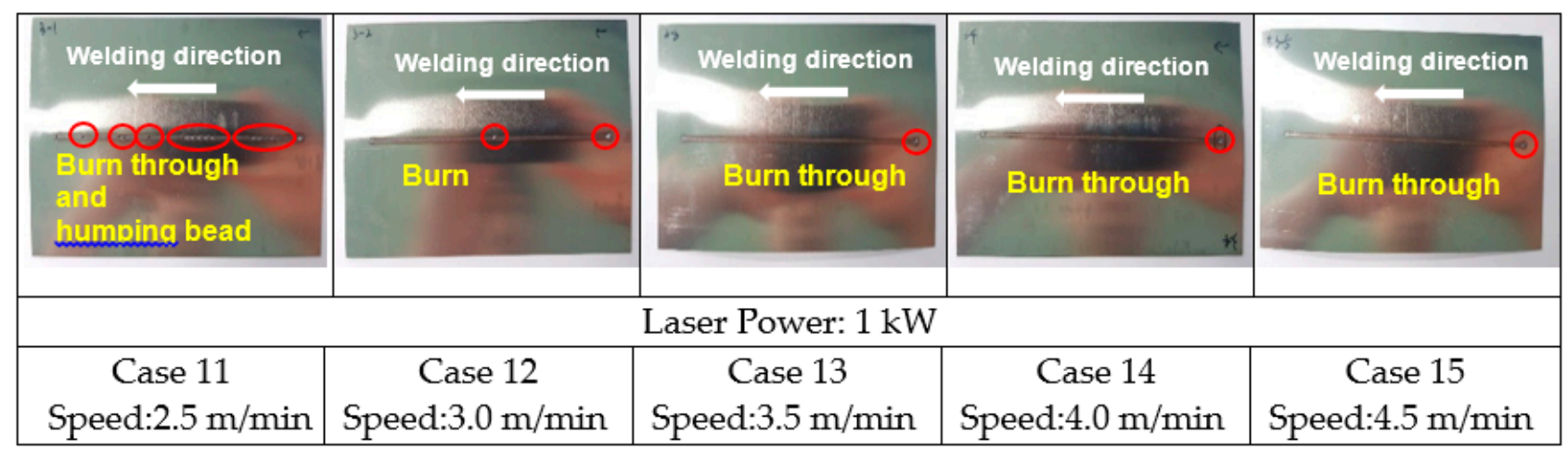

Figure 11. Surface geometry of the third experiment of Lap joint welding.

During the third preliminary experiment, Case 11 showed multiple points of burn through. In Case 12, there was burn through at the starting point and the center of welding. In Cases 13, 14, and 15, there was burn through at the starting point of welding, but sufficient penetration depth and back bead were created. The burn through that occurs at the starting point of welding can be solved through welding output pulse control.

\subsection{Analysis of Cross-Section Observation Results}

A cross-sectional analysis was performed based on the third preliminary test specimen. The specimen was taken from the center of the welding part and the cross-sectional observation results are shown in Figure 12.
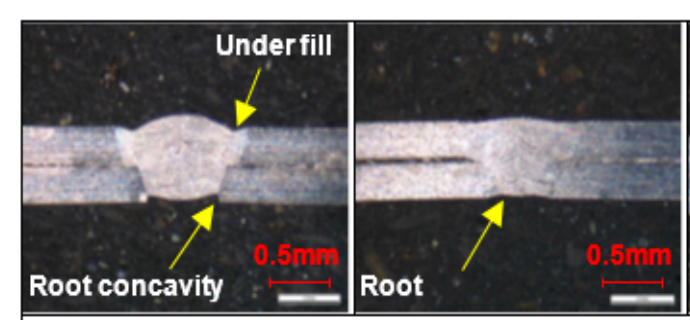

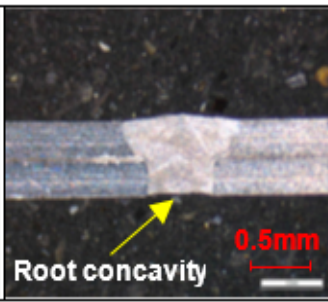

Laser Power: $1 \mathrm{~kW}$

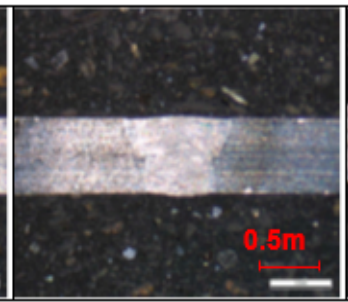

Case 14

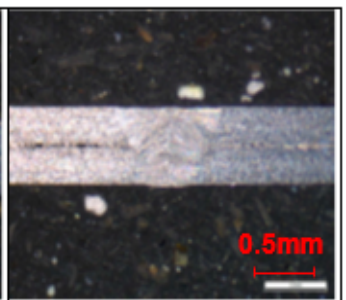

Case 15

Speed: $4.5 \mathrm{~m} / \mathrm{min}$

Figure 12. Bead geometry of Lap joint welding.

Through a visual observation, no internal crack was found in the welding part in Cases 11 to 15, but there were under fill and root concavity in Case 11 and root concavity in Cases 12 and 13. In Cases 14 and 15, there were complete penetration and back bead without any visible cracks or porosity. Next, the top bead width, top bead height, weld zone width, back bead width, back bead height, and penetration of Cases 11 to 15 were measured as shown in Figure 13. Table 6 shows the cross-sectional observation results and the measured values for each welding condition.

Table 6. Sectional observation measurement result.

\begin{tabular}{ccccccc}
\hline Case & $\begin{array}{c}\text { Bead } \\
\text { Width } \\
(\mathbf{m m})\end{array}$ & $\begin{array}{c}\text { Bead } \\
\text { Height } \\
\mathbf{( m m )}\end{array}$ & $\begin{array}{c}\text { Weld } \\
\text { Zone } \\
\mathbf{( m m})\end{array}$ & $\begin{array}{c}\text { Back Bead } \\
\text { Width } \\
\mathbf{( m m )}\end{array}$ & $\begin{array}{c}\text { Back Bead } \\
\text { Height } \\
\mathbf{( m m}\end{array}$ & $\begin{array}{c}\text { Penetration } \\
\mathbf{( m m})\end{array}$ \\
\hline 11 & 0.690 & 0.105 & 0.620 & 0.485 & -0.018 & 0.716 \\
12 & 0.812 & 0.030 & 0.559 & 0.423 & -0.021 & 0.648 \\
13 & 0.766 & 0.051 & 0.499 & 0.433 & -0.020 & 0.654 \\
14 & 0.704 & 0.020 & 0.485 & 0.448 & 0.025 & 0.670 \\
15 & 0.698 & 0.004 & 0.474 & 0.435 & 0.027 & 0.663 \\
\hline
\end{tabular}




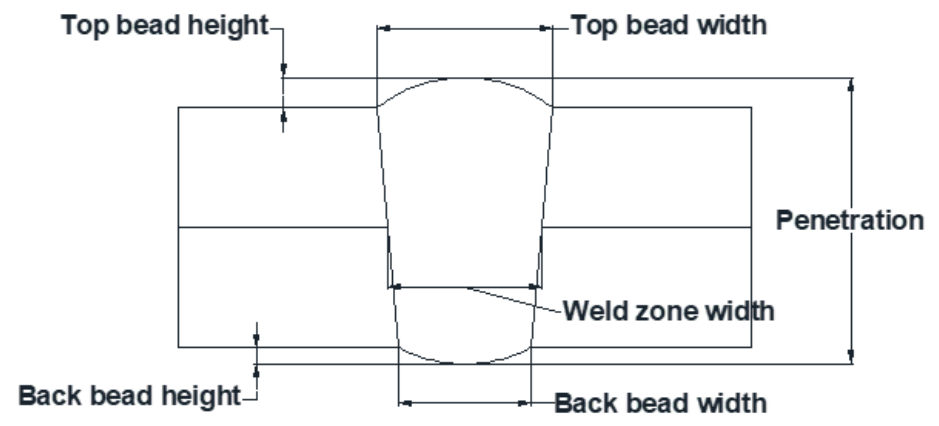

Figure 13. Sectional observation measurement location.

As Table 6 shows, Cases 11, 12, and 13 showed a negative value for the back bead height. If the back bead height value is negative, it is considered that root concavity has occurred. In other words, Cases 11, 12, and 13 showed welding defects due to the occurrence of root concavity. Cases 14 and 15 have positive values for the back bead height, meaning back beads were successfully created. Next, the values measured from cross-sectional observation were compared and analyzed for each laser speed. The trends of top bead width, top bead height, weld zone width, back bead width, back bead height, and penetration depending on laser speed increase are as shown in Figure 14 below.

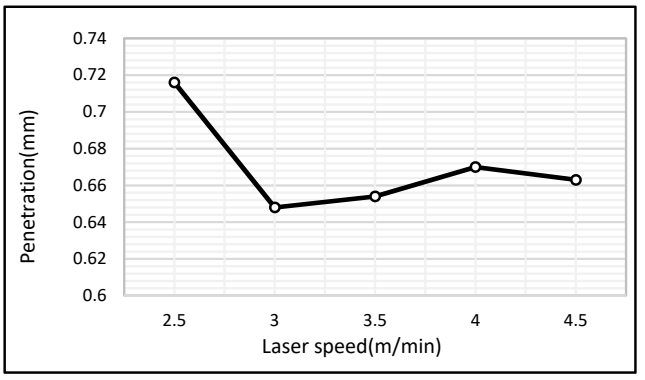

(a)

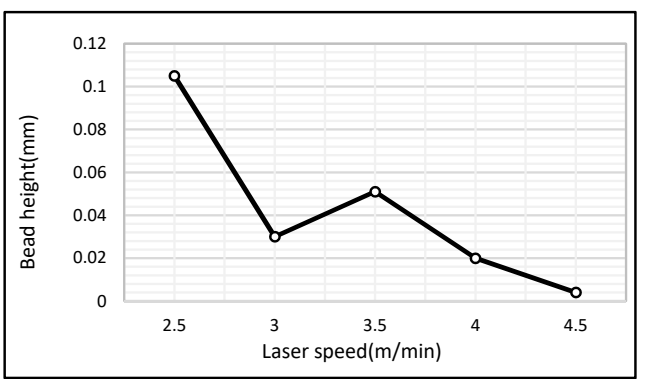

(c)

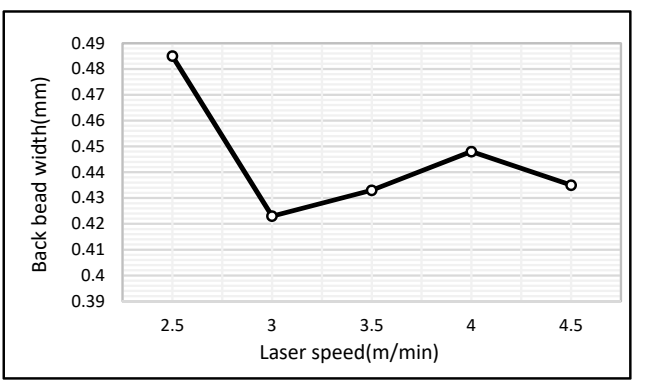

(e)

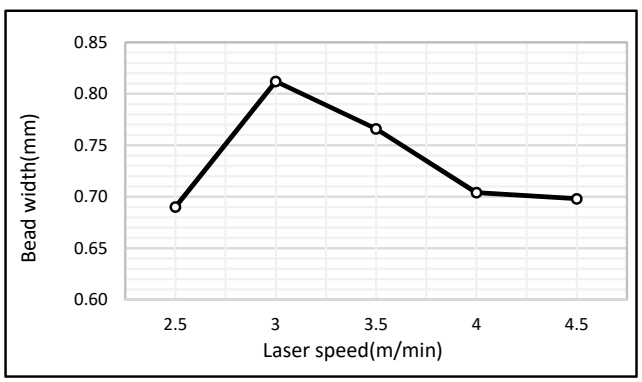

(b)

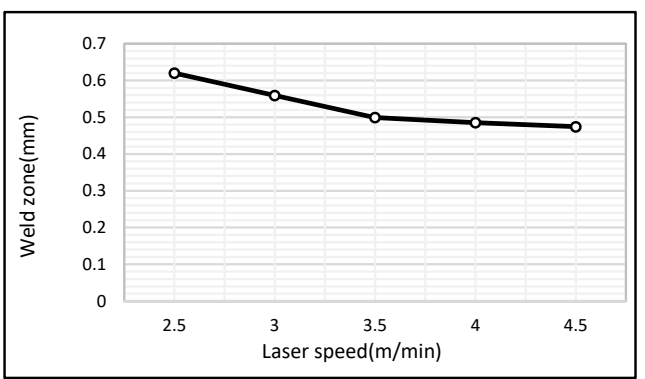

(d)

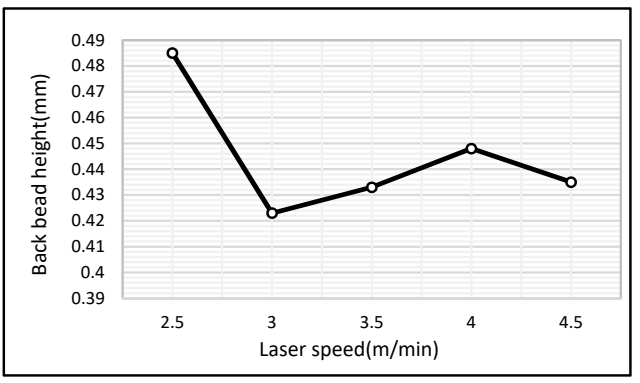

(f)

Figure 14. Changes in section observation measurement values.(a) Penetration; (b) Bead width; (c) Bead height (d) Weld zone; (e) Back bead width; (f) Back bead height. 
In Figure 14, it is not easy to see the tendency related to laser speed at $2.5 \mathrm{~m} / \mathrm{min}$, $3.0 \mathrm{~m} / \mathrm{min}$, and $3.5 \mathrm{~m} / \mathrm{min}$ conditions in (a) Penetration, (e) Back bead width, and (f) Back bead height. This is because the value has been affected by the occurrence of root concavity. As the laser speed increased, the (b) Bead width, (c) Bead height, and (d) Weld zone values tended to decrease. It was confirmed that the back bead was created under the conditions of laser speed $4.0 \mathrm{~m} / \mathrm{min}$ and $4.5 \mathrm{~m} / \mathrm{min}$ in the (f) Back bead height graph.

\subsection{Shear Strength Test}

From the results of the cross-sectional analysis in Section 3.1, the optimum conditions Case 14 for lap joint fiber laser welding for $0.25 \mathrm{~mm}$ ASTM F1684 can be identified. When $\sigma=\mathrm{P} / \mathrm{A} 1, \tau=\mathrm{P} / \mathrm{A} 2$, a fracture occurs in a base metal if the tensile stress $(\sigma)$ is greater than the shear stress $(\tau)$ when the load $(\mathrm{P})$ applied to the welding part is the same and the welding line is the same, as shown in Figure 15. To prevent the breakage of a welding part and induce the breakage of a base metal, Cases 14 and 15 were selected, where the WL (weld line) was $0.25 \mathrm{~mm}$ or more and the back bead was created.

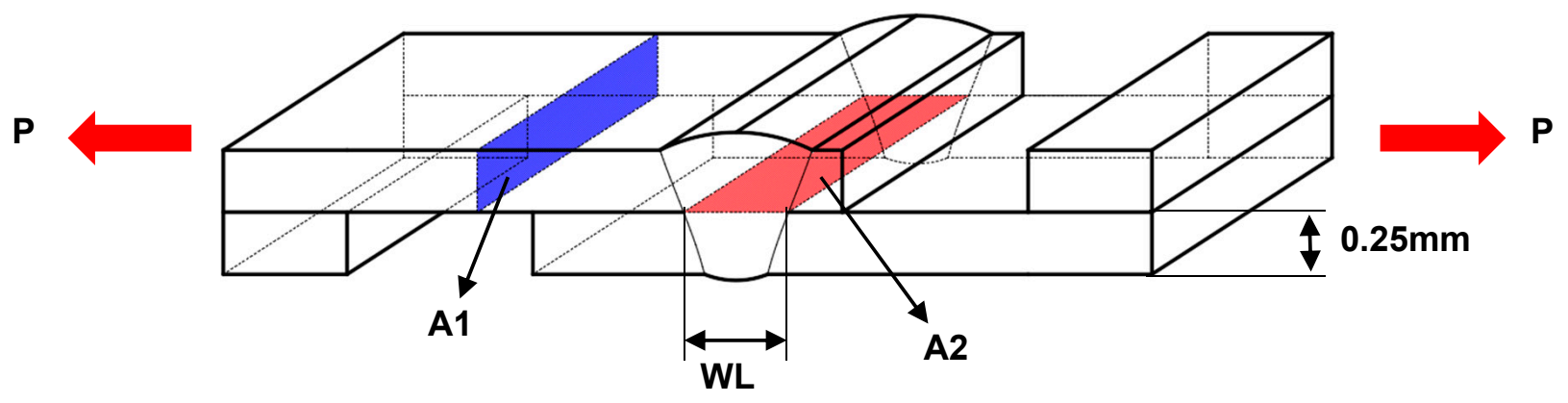

Figure 15. Shear strength prediction model.

A total of eight repeated experiments were performed, i.e., four times each under Cases 14 and 15 welding conditions, and the results of the shear strength test are as shown in Tables 7 and 8.

Table 7. Case 14 shear strength test result.

\begin{tabular}{cccc}
\hline \multirow{2}{*}{ Case \# } & \multicolumn{2}{c}{ Specimen Size $\mathbf{( m m )}$} & \multirow{2}{*}{ Max Force (N) } \\
\cline { 2 - 3 } & Thick & Width & 2043 \\
Case 14_1 & 0.25 & 20.22 & 2045 \\
Case 14_2 & 0.25 & 19.97 & 2050 \\
Case 14_3 & 0.25 & 20.14 & 1998 \\
Case 14_4 & 0.25 & 20.15 & 2034 \\
\hline & Average & 20.94 \\
\hline
\end{tabular}

Table 8. Case 15 shear strength test result.

\begin{tabular}{cccc}
\hline \multirow{2}{*}{ Case \# } & \multicolumn{2}{c}{ Specimen Size $\mathbf{( m m )}$} & \multirow{2}{*}{ Max Force (N) } \\
\cline { 2 - 3 } & Thick & Width & 2008 \\
Case 15_1 & 0.25 & 20.00 & 2048 \\
Case 15_2 & 0.25 & 19.90 & 1988 \\
Case 15_3 & 0.25 & 19.61 & 2043 \\
Case 15_4 & 0.25 & 20.23 & 2021.75 \\
\hline & Average & 24.84 \\
\hline
\end{tabular}


In the shear tension test of the fillet joint, only the maximum load value was presented at the time of shear tension because interfacial failure occurred at the weld. As shown in Tables 7 and 8, it was confirmed that the average max force value of Case 14 was $2034 \mathrm{~N}$ and the average value of Case 15 was $2021.75 \mathrm{~N}$. After the shear strength test, the fracture appearance of each case was observed, as shown in Figures 16 and 17.

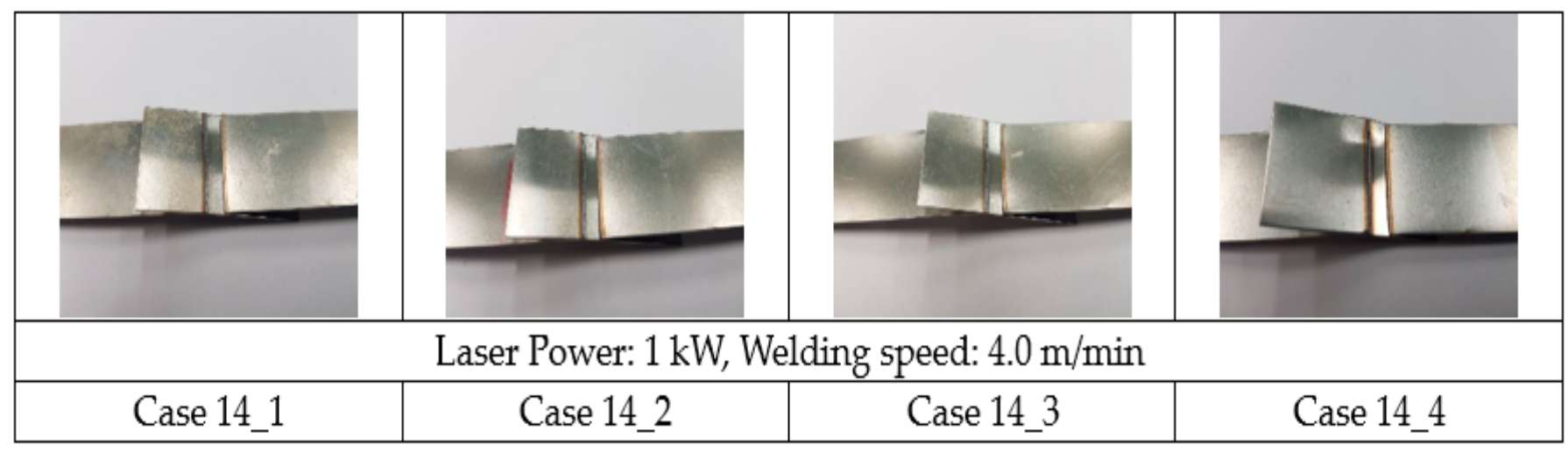

Figure 16. Case 14 condition appearance shape after shear fracture.

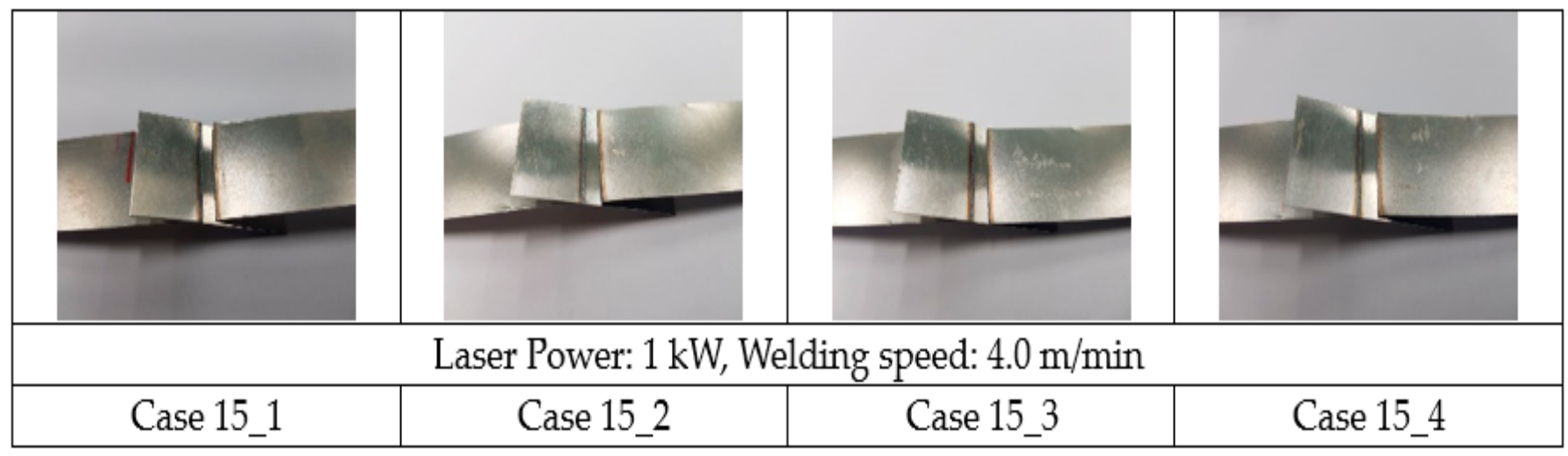

Figure 17. Case 15 condition appearance shape after shear fracture.

Observing the fracture appearance, it was found that under all conditions a fracture occurred at the interface of a welding part, not the base metal.

\subsection{Temperature Measurement of Welding Part}

The temperature in the vicinity of the welding part was measured in order to check the heat-affected zone of the fiber laser of $0.25 \mathrm{~mm}$ thick ASTM F1684. A reproduction experiment was performed by applying the welding conditions of Case 14, which did not show welding defects in the cross-sectional analysis, as shown in Section 3.1. To measure the temperature, one thermocouple was attached to each of the top and back surfaces. The temperature was measured at four locations, i.e., $1 \mathrm{~mm}, 10 \mathrm{~mm}, 20 \mathrm{~mm}$, and $30 \mathrm{~mm}$, as shown in Figure 18 to check the temperature at a location as close to the welding line as possible, and the actual attachment is shown in Figure 19. 


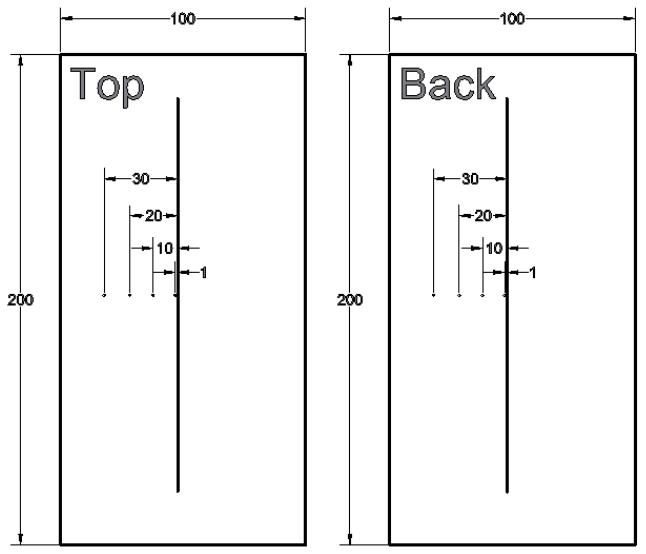

Figure 18. Schematic diagram of thermocouple attachment location.

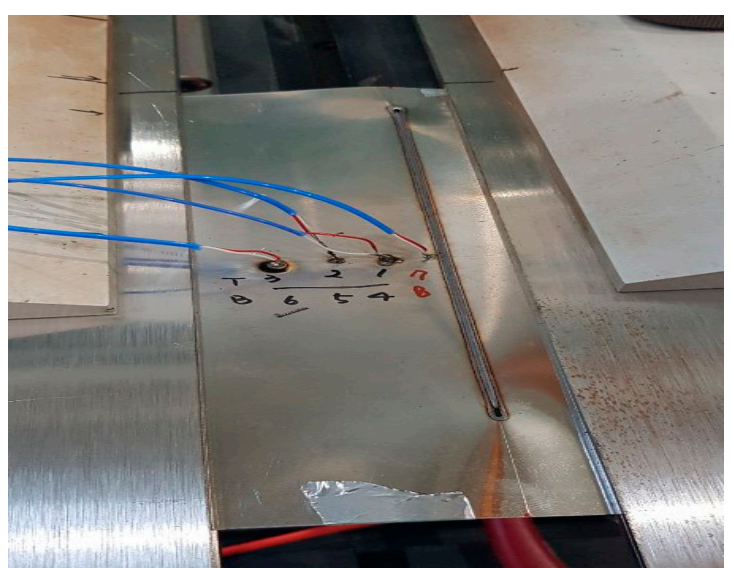

(a) Experiment top thermocouple location

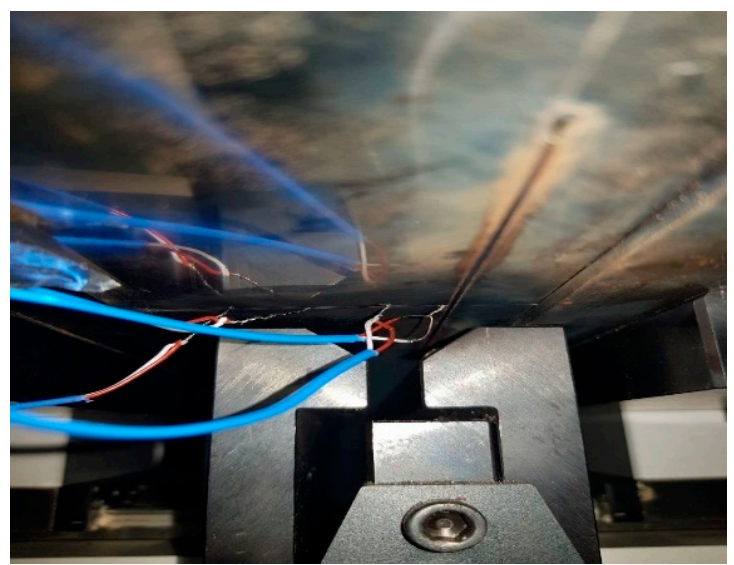

(b) Experiment back thermocouple location

Figure 19. Thermocouple setting.

The highest temperature of $203{ }^{\circ} \mathrm{C}$ was measured at a location $1 \mathrm{~mm}$ from the welding part. The temperature distribution chart obtained from the temperature measurements is shown in Figure 20.

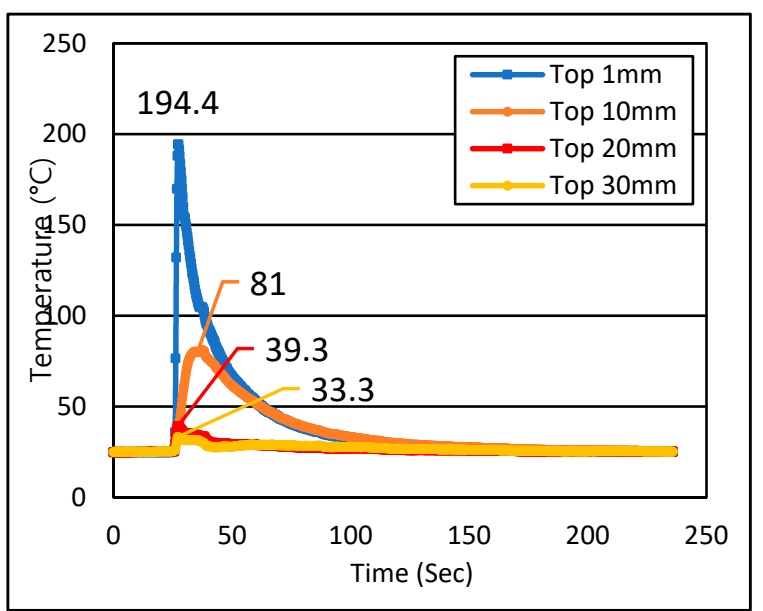

(a) Top temperature

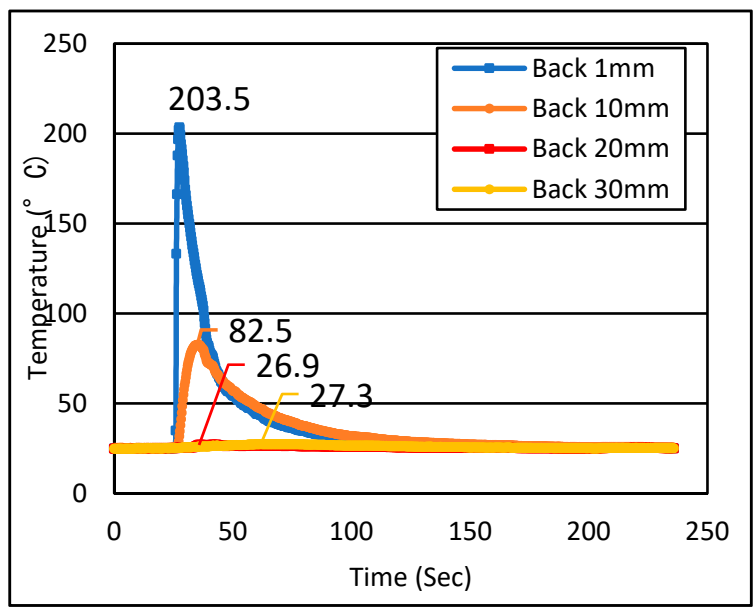

(b) Back temperature

Figure 20. Temperature distribution graph. 
By comparing top and back, it was confirmed that similar temperature distributions. Thickness is thought to have no effect on the temperature because the experiment was conducted on thin sheet materials with high thermal conductivity. By comparing distance away the weld line, it was found that as the distance from became smaller, the temperature increased. In addition, the temperature decrease per distance showed a non-linear tendency. The maximum temperature and the time when the maximum temperature occurs are shown in Table 9.

Table 9. Maximum temperature and the time when the maximum temperature.

\begin{tabular}{ccccc}
\hline $\begin{array}{c}\text { Distance from } \\
\text { Welding Line (mm) }\end{array}$ & $\begin{array}{c}\text { Max Temp. }\left({ }^{\circ} \mathbf{C}\right) \\
\text { of Top Plate }\end{array}$ & $\begin{array}{c}\text { Time (s) at } \\
\text { Max Temp. }\end{array}$ & $\begin{array}{c}\text { Max Temp. }\left({ }^{\circ} \mathbf{C}\right) \\
\text { of Back Plate }\end{array}$ & $\begin{array}{c}\text { Time (s) at } \\
\text { Max Temp. }\end{array}$ \\
\hline 1 & 194.40 & 27.25 & 203.50 & 27.5 \\
10 & 81.00 & 37.50 & 82.50 & 35.00 \\
20 & 39.30 & 27.25 & 26.90 & 35.75 \\
30 & 33.30 & 27.25 & 27.30 & 61.75 \\
\hline
\end{tabular}

\section{Discussion}

In this study, fiber laser welding was applied to the lap joint for $0.25 \mathrm{~mm}$ thick ASTM F1684 and an experiment was performed to derive the optimum conditions. As an additional experiment, three tensile strength tests were performed on a base metal specimen $370 \mathrm{~mm} \times 20 \mathrm{~mm} \times 0.25 \mathrm{~mm}$ in size, which is the same as the shear tensile strength test specimen from the welding part in Figure 7 . The base metal was cut to a size of $200 \mathrm{~mm} \times 20 \mathrm{~mm} \times 0.25 \mathrm{~mm}$ in the directions of $0^{\circ}$ and $90^{\circ}$, and tensile strength tests were performed three times each. Nine tensile strength tests were performed and then the results were compared to the strength of the welding part. Table 10 shows the maximum load value when the base metal breaks.

Table 10. Base material shear strength test result.

\begin{tabular}{cccc}
\hline CASE & Length $(\mathbf{m m})$ & Rolling Direction $\left.\mathbf{(}^{\circ}\right)$ & Max Force (N) \\
\hline Base metal 1 & 370 & 0 & 2395 \\
Base metal 2 & 370 & 0 & 2308 \\
Base metal 3 & 370 & 0 & 2325 \\
\hline Base metal 4 & 200 & 0 & 2275 \\
Base metal 5 & 200 & 0 & 2318 \\
Base metal 6 & 200 & 0 & 2285 \\
\hline Base metal 7 & 200 & 90 & 2243 \\
Base metal 8 & 200 & 90 & 2238 \\
Base metal 9 & 200 & 90 & 2280 \\
\hline \multicolumn{4}{c}{ Average } \\
\hline
\end{tabular}

As shown in Table 10, it was confirmed that there was no difference in tensile strength depending on the direction of a base metal. In addition, even if the length of a specimen was varied and the experiment was performed in UTM, it was confirmed that there was no effect related to the length. The average maximum load of ASTM F1684 base metal is $2296.33 \mathrm{~N}$ and the tensile strength of the welding part is about $88.6 \%$ that of the base metal because $2034 \mathrm{~N}$ is the average maximum load of the lap joint welding part, as shown in Table 6.

Fiber laser welding has a volumetric speed that is 2 to 10 times faster than typical arc welding, which means that a shorter manufacturing time and excellent quality without defects can be expected when applied to thin plate ASTM F1684 welding due to its low welding deformation. 


\section{Conclusions}

In this study, fiber laser welding was applied to lap joint welding of $0.25 \mathrm{~mm}$ thick ASTM F1684 to identify welding conditions that can lead to excellent welding quality and to analyze the maximum temperature during welding. The summary of the findings is as follows.

1. The conditions required for excellent lap joint welding quality of $0.25 \mathrm{t}$ ASTM F1684 were a welding power of $1 \mathrm{kw}$ and a welding speed of $4.0 \mathrm{~m} / \mathrm{min}$ or $4.5 \mathrm{~m} / \mathrm{min}$. When welding at the above conditions, it was confirmed that excellent quality was obtained by securing sufficient beads on the back side.

2. The tensile strength of a welding part was compared with that of a base metal after lap joint welding under the condition that sufficient beads appeared on the back side. When the width was $20 \mathrm{~mm}$ and the thickness was $0.25 \mathrm{~mm}$, the tensile strength of the base metal was $2296.33 \mathrm{~N}$ and the tensile strength of the welding specimen was $2034 \mathrm{~N}$, which was $88.6 \%$ that of the base metal.

3. By comparing top and back, it was confirmed that similar temperature distributions were shown. In addition, it was confirmed that the maximum temperature at a location $1 \mathrm{~mm}$ from the welding line was $203.5^{\circ} \mathrm{C}$, and the maximum temperature at a location $10 \mathrm{~mm}$ away was $81^{\circ} \mathrm{C}$.

Author Contributions: Conceptualization, J.K. (Jaewoong Kim) and Y.K. (Younghyun Kim); methodology, J.K. (Jisun Kim); validation, D.K., and C.P.; formal analysis, S.K.; investigation, C.P.; resources, Y.K. (Yongtai Kim) and D.K.; data curation, J.K. (Jaewoong Kim); writing—original draft preparation, J.K. (Jaewoong Kim), Y.K. (Younghyun Kim); writing—review and editing, C.P.; supervision, C.P.; project administration, J.K. (Jaewoong Kim), Y.K. (Yongtai Kim); funding acquisition, J.K. (Jaewoong $\mathrm{Kim})$. All authors have read and agreed to the published version of the manuscript.

Funding: This research was financially supported by the Korea Institute of Industrial Technology (KITECH) through the Research and Development "The dynamic parameter control based smart welding system module development for the complete joint penetration weld" (PEH21035).

Data Availability Statement: The data presented in this study are available on request from the corresponding author.

Conflicts of Interest: The authors declare no conflict of interest.

\section{References}

1. Li, K.; Wu, M.; Gu, X.; Yuen, K.; Xiao, Y. Determinants of ship operators' options for compliance with IMO 2020. Transp. Res. Part $D$ Transp. Environ. 2020, 86, 102459. [CrossRef]

2. Xu, H.; Yang, D. LNG-fuelled container ship sailing on the Arctic Sea: Economic and emission assessment. Transp. Res. Part D Transp. Environ. 2020, 87, 102556. [CrossRef]

3. Hwang, S.; Jeong, B.; Jung, K.; Kim, M.; Zhou, P. Life Cycle Assessment of LNG Fueled Vessel in Domestic Services. J. Mar. Sci. Eng. 2019, 7, 359. [CrossRef]

4. Van, T.; Ramirez, J.; Rainey; Ristovski, Z.; Brown, R. Global impacts of recent IMO regulations on marine fuel oil refining processes and ship emissions. Transp. Res. Part D Transp. Environ. 2019, 70, 123-134. [CrossRef]

5. Seddiek, I.; Elgohary, M. Eco-friendly selection of ship emissions reduction strategies with emphasis on SOx and NOx emissions. Int. J. Nav. Archit. Ocean Eng. 2014, 6, 737-748. [CrossRef]

6. Choi, Y.; Ahn, J.; Jo, C.; Chang, D. Prismatic pressure vessel with stiffened-plate structures for fuel storage in LNG-fueled ship. Ocean Eng. 2020, 196, 106829. [CrossRef]

7. Kim, B.; Park, J.; Lee, J.; Kim, M. Study on the Initial Design of an LNG Fuel Tank using 9 wt.\% Nickel Steel for Ships and Performance Evaluation of the Welded Joint. J. Weld. Join. 2019, 37, 555-563. [CrossRef]

8. Han, K.; Kim, D.; Yun, K.; Shin, Y.; Lee, H. Effect of Al and Zn-coated Layer of Scaffolding on Weldability of Cryogenic Material in LNG Carriers. J. Weld. Join. 2019, 37, 9-14. [CrossRef]

9. Yang, W.; Kil, W.; Moon, B.; Nam, H.; Kang, N. Tensile and Microstructural Behaviors of Austenitic Stainless Steel GTA Welds for Cryogenic Application. J. Weld. Join. 2020, 38, 400-408. [CrossRef]

10. Park, J.; An, G. Fracture Characteristics of Cryogenic Steel Using Weibull Stress Analysis. J. Weld. Join. 2019, 37, 531-538. [CrossRef]

11. Wang, H.; Hu, S.; Shen, J.; Li, D.; Lu, J. Effect of duty cycle on microstructure and mechanical properties of pulsed GTAW Lap joint of Invar. J. Mater. Process. Technol. 2017, 243, 481-488. [CrossRef] 
12. Qiu, C.; Adkins, N.; Attallah, M. Selective laser melting of Invar 36: Microstructure and properties. Acta Mater. 2016, 103, 382-395. [CrossRef]

13. Park, W.; Chun, M.; Han, M.; Kim, M.; Lee, J. Comparative study on mechanical behavior of low temperature application materials for ships and offshore structures: Part I-Experimental investigations. Mater. Sci. Eng. A 2011, 528, 5790-5803. [CrossRef]

14. Harrison, N.; Todd, L.; Mumtaz, K. Thermal expansion coefficients in Invar processed by selective laser melting. J. Mater. Sci. 2017, 52, 10517-10525. [CrossRef] [PubMed]

15. Yakout, M.; Cadamuro, A.; Elbestawi, M.; Veldhuis, S. The selection of process parameters in additive manufacturing for aerospace alloys. Int. J. Adv. Manuf. Technol. 2017, 92, 2081-2098. [CrossRef]

16. Zhan, X.; Liu, Y.; Ou, W.; Gu, C.; Wei, Y. The Numerical and Experimental Investigation of the Multi-layer Laser-MIG Hybrid Welding for Fe36Ni Invar Alloy. J. Mater. Eng. Perform. 2015, 24, 4948-4957. [CrossRef]

17. Zhan, X.; Li, Y.; Ou, W.; Yu, F.; Chen, J.; Wei, Y. Comparison between hybrid laser-MIG welding and MIG welding for the invar36 alloy. Opt. Laser Technol. 2016, 85, 75-84. [CrossRef]

18. Jasthi, B.; Arbegast, W.; Howard, S. Thermal Expansion Coefficient and Mechanical Properties of Friction Stir Welded Invar (Fe-36\%Ni). J. Mater. Eng. Perform. 2009, 18, 925-934. [CrossRef]

19. Zhao, Y.; Sato, Y.; Kokawa, H.; Wu, A. Microstructure and properties of friction stir welded high strength Fe-36 wt $\%$ Ni alloy. Mater. Sci. Eng. A 2011, 528, 7768-7773. [CrossRef]

20. Corbacho, J.; Suarez, J.; Molleda, F. Grain Coarsening and Boundary Migration during Welding of Invar Fe-36Ni Alloy. Mater. Charact. 1998, 41, 27-34. [CrossRef]

21. Kim, D.; Pyo, C.; Kim, J.; Kim, J.; Lee, H. A Study on Cross-Shaped Structure of Invar Material Using Cold Wire Laser Fillet Welding (PART I: Feasibility Study for Weldability). Metals 2020, 10, 1385. [CrossRef] 